\title{
NABATAEAN AGRICULTURAL TERMINOLOGY
}

\author{
MAHDI ALZOUBI \\ Queen Rania Institute of Tourism and Heritage, The Hashemite University-Jordan \\ P.O. Box 150450, Zarqa 13115, Jordan \\ e-mail: mahdi@hu.edu.jo
}

This research is an analytical study of the agrictural terms that occur on Nabataean inscriptions. It is an attempt to explore their linguistic derivation, meanings and indications seeking to reach a better understanding of the Nabataean agricultural system and activities. We will also try to compare these terms to their parallels in other Semitic languages and dialects.

Key words: Nabataean inscriptions, Semitic inscriptions, Nabataean agriculture, agricultural terms, Nabataean society.

\section{Introduction}

Nabataean inscriptions, extended over a vast area of Transjordan, the Negev, the Sinai Peninsula, southern Syria and northwestern Arabia, provide ample information on economic, legal, social and daily life of the Nabataeans. Thus, the Nabataean agricultural terms and expressions, surfacing in many inscriptions of different types, reveal many aspects of the agricultural activities known in the Nabataean society. Especially the contracts of sales of palm trees from the Dead Sea region are of interest, but the funerary, dedicatory and constructive inscriptions also yield additional data on agricultural terms.

\section{Notes on Nabataean Agriculture}

Agricultural activities were a major resource for Nabataeans to meet the food requirements of the population of the kingdom. Nabataeans exploited the fertile land, mainly of Edom and Moab, in their agricultural activities (Glueck 1965, pp. 197-198). The 
true development of Nabataean agriculture began during the rule of Aretas IV (9 B.C.40 A.D.) and intensified through the last decades of the 1st century B.C. (Bowersock 1983, pp. 385-388; Negev 1986, pp. 45-46).

Due to the semi-arid nature of the area occupied by the Nabataeans, they adapted special techniques to their agricultural activities. Archaeological investigations reveal extensive water management and agricultural productions in and around the ancient city of Petra. Nabataeans built water channels to collect the rainfall and store it in cisterns and dams carved inside the rocks for drinking and for agricultural purposes. Diodorus (see Siculus-Oldfather 1935, p. 94) noted: "As the earth in some places is clayey and in others is of soft stone, they make great excavations in it, the mouths of which they make very small, but by constantly increasing the width as they dig deeper, they finally make them of such size that each side has a length of about 100 feet. After filling these reservoirs with rain water, they close the openings, making them even with the rest of the ground, and they leave signs that are known to themselves but are unrecognisable to others".

A variety of water engineering systems and water supplies provided by the various dams, water tanks, wells and canals had been cut on the rocks in Petra and in Beida Sites (al-Hamoury 2002, p. 20). Nabataeans used a developed hydraulic water system; archaeological evidence shows that they were experts in water harvesting (Farajat 2008, p. 9).

Nabataeans grew mainly wheat, field crops, olives, grapes and palm trees. Their agricultural productions were not only to meet the demands of their own consumption, but also for trading purposes.

Olive and grape refineries were found in different sites around Petra, Beida and Khirbet al-Dharih where Nabataean peasants used to live near the water resources (Gluck 1965, pp. 197-198).

\section{Nabataean Agricultural Terms}

\section{'yln 'Trees, Palm Trees'}

This term has been noted in the Nabataean contracts of palm trees land sales from Nahal Hever; 'yln: plur. abst. 'Trees'; e.g. Yadin et al. (2002, p. 208, No. $2^{16}$ ):

w'yln klh $w^{c} s\{y\} h$ rțbh wybyšh

all types of trees (or palm trees) and wood (or trees), wet and dry

Yadin $\left(2002\right.$, p. 208, No. $\left.2^{/ 6}\right)$ translated it as trees or palm trees. It could be compared with the Akkadian allānum 'tree' (Gelb 1957, p. 39), or with the Arabic /'l-layen meaning 'palm tree' (Ibn Manzūr 2003, Vol. 8, p. 180). The term has also been noted in JAr. in the form ' $y \ln [y]$ : pl. cnst. 'Trees' (Hoftijzer-Jongeling 1995, p. 46). 
'kry 'farmer, plowman'

'kry is the equivalent of the Akkadian ikkaru 'farmer, plowman' (Kaufman 1974, p. 58). We may also compare it to the Arabic أكرياء al-karū and its plural form akryā'; names derived from the root كَريَ karaya 'to rent, lease' (see Ibn Manzūr 2003, Vol. 9, p. 650).

In Nabataean, the term has been noted in identical contexts on contracts of palm trees land sales from the Dead Sea region; 'kry sing. abst. (see Yardeni 2000, 271 $1^{116}$; $280^{137} ; 284^{115,41}$ ). The term has also been noted in OffAr. as' $k r$ meaning 'farmer' (see Hoftijzer-Jongeling 1995, Vol. 1, p. 53); e.g. Yardeni (2000, p. $\left.280^{137}\right)$ :

kdn hplqt 'by ${ }^{c} d n d^{\prime c}$ l gnt'd' hlq mr' \{n\}' 'kry lšnt'kwt bh s'yn šrh

Accordingly, this (same) 'by ${ }^{c} d n$ has apportioned what is owed from (this) plantation, the share of our lord, the leasing (tax) for a year, as well, in its amount of Se'ah, ten.

The clause $h l q m r$ ' $\{n\}$ ' 'kry lšnt', in the above example, is probably related to certain land tax payable annually to the king for the production of the palm trees. Cotton (1997, pp. 255-265) thinks that this clause seems to be an individual contract between the king and the new possessor of the land.

All the Nabataean texts contain such a clause, the amount of this ' $k r y$ is ten $s^{\prime} y n$. This could refer to the so-called tithe, i.e. one-tenth of one's income. The tithe was practised in the Ancient Near East; literature provides scant evidence for the practice of tithing and the collection of tithes (Jagersma 1981, pp. 116-128). None of the extant laws of the Ancient Near East deal with tithing, though other secondary documents show that it was practised. In the Bible, Mosaic Law required that the Israelites give one-tenth of the produce of their land and livestock, the tithe, to support the Levitical priesthood (Leviticus 27: 30-33).

'r $\mathbf{c}$ 'Field, Land'

The term is of Akkadian origin, it is the equivalent of arrā' $u$ (Hoftijzer-Jongeling 1995, p. 110) and of ersutu (Gelb 1957, p. 66). It has been mentioned in Nabataean inscriptions as ${ }^{c}{ }^{c} n$ : plur. abst. (Yardeni 2000, p. $271^{121}$ ); ${ }^{c} r^{c}$ : sing. cstr. (Yardeni 2000, p. $\left.279^{18}\right)$; ' $r^{c}$ ': sing. emph. (Yardeni 2000, p. $296^{18}$; CIS II $964^{1 / 3}$ ); e.g. Yadin et al. (2002, p. 178 , No. $\left.1^{/ 21}\right)$ :

\section{whrp w $w^{c} l l h w^{\prime} r^{c} n$ wkrmyn}

and dates (or crops) and harvest and land parcels and vineyards

This term has also been noted in Ph.: 'rș sing. cstr. (RES 287/3 $; 288^{12}$ ), 'rșt plur. abs. (KAI $14^{19}$ ); in Pun.: ' $r s ̦$ (KAI $121^{11}$ ), plur. abs. (KAI 141 ${ }^{11}$ ); ['] $r s ̦$ 't (KAI $161^{199}$ ); in Mo.: 'rss sing. abst. (KAI $181^{129,31}$ ), 'rș sing. cstr. (KAI 181 110 ); in OldAr.: sing. abs. ' $r q$ (KAI 222 A 26); ' $r q$ ' sing. emph. (KAI $216^{14}$ ); in OffAr.: ' $r q$ sing. abs. (Cowley 1967, $8^{1 / 3}$ ), 'rq' sing. emph. (CIS II $1^{11}, 2^{12}, 3^{12}$ ), ' $r$ ' : sing. cstr. (Segal 1983, No. $3^{15}$ ), sing. emph. (Cowley 1967, pp. $5^{16}, 16^{16}$ ), 'rqt: plur. cstr. (Delaporte 1912, 
No. 77), 'rqt': plur. emph. (Drive 1957, $12^{/ 6}$ ); in JAr. ' $r{ }^{c} h$ : sing. emph. (FitzmyerHarrington 1978, A $22^{15}$ ) and in Palm. ' $r^{c}$ (Cantineau 1936, p. $271^{17}$ ).

b'rwt 'wells, cisterns'

The term has been noted only in one Nabataean inscription (CIS II 350) in the form b'rwt: plur. cstr. means 'wells, cisterns':

wbty'dy bhn wgny'wgnt smk'wb'rwt my'

and the rooms within it and the gardens and the Triclinium-garden and the wells of water.

The term has also been mentioned in Pun. and in OffAr. as sing. abs. $b$ 'r (Hoftijzer-Jongeling 1995, p. 141). It is the equivalent of the Akkadian bürtu (CAD Vol. 2, p. 335) and the Syriac bi'rē (Healey 1993, p. 240). We can also compare it to

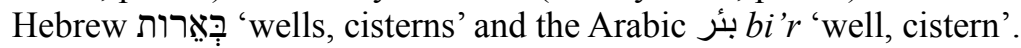

\section{jb' 'Cistern'}

$j b$ ' is sing. emph. attested only in one example in Nabataean (RES $1432^{11}$ ):

'lh șryh' $z^{c} y r$ 'wjb' $d y^{c} b d$ 'șlh

this is the small tomb and the well which 'ṣlh made

It is the equivalent of the Arabic جُب Jub 'water tank for storing water in building or underground reservoir for rainwater' (Ibn Manzūr 2003, Vol. 2, p. 11), and the Syr. Jubā (Cantineau 1931-1932, p. 76). The term has also been attested in Palm.: $j b^{\prime}\left(\operatorname{RES~} 1432^{1 /}\right)$.

\section{tmr 'date palm'}

This term is the equivalent of Arabic تمر תמָר tamr and Hebrew 'date palm'. It has been mentioned in Nabataean contracts of palm trees land sales; tmry': sing. emph. (Yardeni 2000, p. 265, 1. 14; 2013, p. 285, 1. 23), tmryn: plur. abs. (Yardeni 2000, p. 279, 1. 26).

The term has also been mentioned in Hebrew; tmryn: plur. abs. (Naveh 1978, $49^{\prime 5}$ ), in OffAr. tmrn: plur. abs. (Delaporte 1912, Nos $46^{11}, 72^{\prime 2}$ ) tmry' plur. emph. (Cowley 1967, p. 81) and in JAr. tmr': sing. emph. (Milik 1968, p. 101, 1. 4); e.g. Yadin et al. $\left(2002\right.$, p. 210 , No. $\left.2^{/ 26}\right)$ :

wtmryn wsq[myn w'y]ln [k]lh

and dates and syca[mores, and a]ll types of [tr]ees

$\mathbf{z r}^{\mathbf{c}}$ 'to sow, to plant'

The verb $z r^{c}$ is of Akkadian origin; zarû 'to sow' (CAD Vol. 21, p. 70). It is the

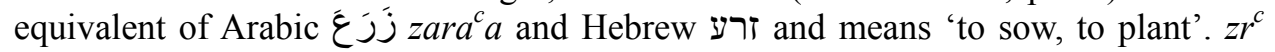


has been attested in Nabataean in the form $z r^{c}$ : part. act. 'sower, farmer', and in the form $z r^{c}$ ': sing. emph. 'the sower'; e.g. Yardeni (2000, p. 296, 1. 6):

' $h w^{\prime} z r^{c} w^{c} m l w^{c} l y y h w^{\prime c} m l ' w z r^{c}$,

I will be sower and worker and it will be on my charge the Sow and the Work.

The term has been noted in OldAr. $y z r^{c}$ : impf. 3p.s.m. (KAI 222A 36), $l z r^{c}$ : prep.+qal. pf. 3p.s.m.; $z r^{c} h$ : sing. + suff. 3 p.s.m., in OffAr. $t z r^{c} n h: 2$ p.s.m. + suff. 3 p.s.f., mzrch: inf.+suff. 3p.s.m. (Hoftijzer-Jongeling, 1995, pp. 340-341), $z r^{c}$ : sing. abs. (Cowley 1967, p. $13^{/ 8}$ ), $z r^{c}$ : sing. cstr. (RES $493^{/ 2}$ ), in JAr. $z r^{c} n h$ : qal. imper. s.m.+suff. 3p.s.m. (Milik 1968, p. 101, 1. 14), $z r^{c}$ : sing. abs. (Fitzmyer-Harrington 1978 , p. $52^{12}$ ) in Ph. $z r^{c}$ : sing. abs. (KAI $14^{/ 8}$ ), $z r^{c}$ : sing. cstr. (KAI $14^{111}$ ), $z r^{c} w$ : sing.+suff. 3p.s.m. (KAI $10^{/ 15}$ ), $z r^{c} y$ : sing. + suff. 1p.s. (KAI $43^{111,15}$ ), $z r^{c} m$ : sing. + suff. 3p.pl.m. (KAI 14 $4^{/ 22}$ ), in Hebrew $z r^{c}$ : sing. abs. (KAI $182^{/ 1 f}$ ) in Samal. $z r^{c}$ : sing. cstr. (KAI $214^{/ 20}$ ) and in Palm. $z r^{c}$ : sing. cstr. (CIS II $4218^{/ 5}$ ).

\section{ybyšh 'dry, sec'}

The term has been noted in the Nabataean contracts of sales of palm trees. It is the equivalent of the Arabic يابسه / yābisah 'dry, sec'. The term has also been noted in JAr.: plur. m. abs. ybyšyn (Naveh 1978, 49 ${ }^{14}$ ) and in Palm. yby̌̌: sing. m. abs. (CIS II 3913); e.g. Yardeni (2000, pp. 862-887):

w'yln klh w'ṣh rtybh wybyšh

and all type of trees, and wood, wet and dry

s'yn 'Measure of capacity used in connection with grain'

$s$ ' $y n$ is the plur. abs. of $s ' h$. 'Measure of capacity used in connection with grain'. It could be compared with the Akkadian sūtu and the Greek $\sigma \alpha \dot{\tau} o v$ (Hoftijzer-Jongeling 1995, p. 772). We can also compare it to the Arabic $s \bar{a}^{c}$ which refers to a measure of capacity used in connection with grain, it equals three kilograms.

The term has also been attested in Hebrew $s$ ' $h$ (Benoit-Milik-de Vaux 1961, p. 24): sing. abs., $s^{\prime} y m$; in OffAr. $s^{\prime} h$ : sing. abs. (Delaporte 1912, p. $69^{\prime 2}$ ), $s^{\prime} n$ : plur. abs. (Cowley 1967, p. 63 $3^{1 / 3}$ ) and in JAr. $s^{\prime} y n$ (Fitzmyer-Harrington 1978, p. 52/2): plur. abs., ś'yn (Yadin-Greenfield 1989, p. 21).

\section{šqy' 'waterwheel, irrigation ditches'}

$\check{s} q y$ ' is a sing. m. emph. derived from the verb šqy 'to irrigate'. It is the equivalent of the Arabic ساقية sāqeyat 'waterwheel': name derived from the verb سقية saqaya 'to irrigate'. We can also compare it with the Akkadian šaqû (Gelb 1957, p. 282).

The term has been noted in the Nabataean contracts of palm trees land sales from Naḥal Hever; e.g. Yadin et al. (2002, p. 208, No. $3^{24-25}$ ): 
dy bglgl'dy bm[hw] $z^{c}$ gltyn ${ }^{c} l s ̌ s y ' w^{c} n y$ myh plqwt šs h hdh bywm hd which is in Galgala', which is in $\mathrm{Ma}$ [ho] $\mathrm{z}^{\mathrm{c}}$ Eglatin, including irrigation ditches and assigned watering periods; half one hour on the first day of the week.

Yadin thinks that this clause refers to an irrigation arrangement at En-Gedi where water is allocated to every garden according to specific quotas. This tradition is also known from Greek, Latin and Egyptian documents where water right is specified in all of the vineyards (Yadin 1962, p. 294; Yadin et al. 2002, p. 6).

\section{'Il 'harvest, crops'}

This term has been noted in Nabataean contracts of sale of palm trees; ${ }^{c} l l$ (Alzoubi 2012, No. $41^{128}$ ): sing. cstr.; ${ }^{c} l l h$ (Yadin et al. 2002 , No. $1^{121}$, 26), ${ }^{c}$ llt (Yardeni 2000, p. 296, 1. 6). It is the equivalent of the Arabic غُلَّة gallat 'harvest, crops'.

The term has also been noted in OffAr. ${ }^{c} l l t$ : plur. cstr. (Hoftijzer-Jongeling 1995, Vol. II, p. 858); e.g. Yadin et al. (2002, p. 271, 1. 21):

wmšh whrpw ${ }^{c} l l h$

and oil and dates and harvest

\section{ḥrrh 'arid land'}

The term has been attested in Nabataean contracts of sale of palm trees, it has been noted in the clauses concerning the plantation description; $w^{\prime} r^{c} h r r h$ 'and arid land' (Yadin et al. 2002, No. $2^{/ 26}$ ).

The term could also be read as $h d d h$, but its reading as hrrh sounds more probable. The term could be compared to the Arabic harrah 'area that is full of black or burnt rocks' (see Ibn Manzūir 2003, Vol. 2, p. 389).

• șyh 'Trees' 'wood sticks, tree sticks'

The term is of Akkadian origin; it is the equivalent to ișu and its variants êși, eșu, ișssu 'tree, wood (CAD Vol. 7, pp. 214-215). We can also compare it to the Arabic عصي 'esey which indicates 'wooden staff or tree branches' (see Ibn Manzūr 2003, Vol. 6, p. 292), and with the Hebrew עצ' 'ע 'T 'tree' (see Hoftijzer-Jongeling 1995, pp. 879880). The same form 's ${ }^{c} h$ 'trees' has been noted in Jer. 6:6 (Yadin et al. 2002, p. 222).

The term occurred in Nabataean contracts of sales of palm trees land in the clause related to the alm tree garden proprieties; e.g. Yardeni (2000, pp. 862-887):

$w^{c}$ șh rtybh wybšh

and wood (or trees), wet and dry

krmyn 'vineyards'

The term has been noted in Nabataean as krmyn pl. m. 'vineyards'. It is the equiva-

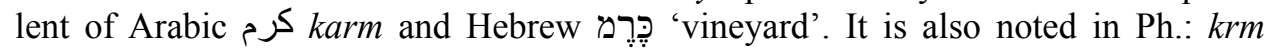
sing. abs., krmm pl. abs., in Amm.: krm sing. abs., Samal. krm sing. abs., OffAr.: krm 
sing. cstr., krm' sing. emph., krmy' plur. emph. (Hoftijzer-Jongeling 1995, p. 536); e.g. Alzoubi (2012, No. $\left.41^{21}\right)$ :

whrp $w^{c} l l h w^{\prime} r^{c} n$ wkrmyn

and dates (or crops) and products and land parcels and vineyard

mṣ̣̌ 'olive oil'

The noun mšh is the equivalent of the Hebrew משח 'olive oil'. It has been noted as sing. abs. in a Nabataean papyri from the Dead Sea Region. The term has been noted in OffAr. as sing. abs. mšh (Cowley 1967, pp. $30^{120}, 31^{120}$ ), and as sing. emph. mšh ' (RES $496^{\prime 3}$ ), and in Palm. as sing. abs. mšh (CIS II 3913 ii 28) and as sing. emph. $m s ̌ h h^{\prime}\left(\right.$ CIS II 3913); e.g. Yadin et al. (2002, No. $\left.1^{126}\right)$ :

26. ....wmšh whrpw ${ }^{c} l l h$

26. ....and olive oil and dates (or crops) and crops

rtybh 'irrigated, wet'

The term can be compared with the Akkadian ruttubu, ritibtu 'irrigated field' (CAD Vol. 14, p. 391). It could be the equivalent of the Arabic ر رطب ratab 'wet, fresh'. The term has been noted on the Nabataean contracts of sale of palm trees; e.g. Yadin et al. (2002, p. 208, No. $2^{/ 6}$ ):

w'yln klh w's $\{y\}$ h rtybh wybyšh

All types of trees (or palm trees) and wood (or trees), wet and dry

nṣn' 'flower'

The term has been noted only in one example in Nabataean. Naveh $(1979$, p. 112) compared it to late Hebrew 'flower':

wpy 'c $m$ šrșt btlt'wnșn'

the accomplishment of the vow with the profusion of closed flowers and sprouting.

btlt' 'closed (virgin) flowers'

The word has been noted only in one Nabataean incantation text (see $n s ̦ n$ ' above). Following Naveh (1979, p. 112) it seems to be a detective spelling of btwlt' 'the virgins' and it may indicate closed (virgin) flowers. We can also compare btlt with the Arabic بنول / batūl 'virgin' and also with the agricultural term which means 'shoot, short peace of plant'.

ḥrp 'dates, or early crops'

This term has been mentioned in the Nabataean contracts of sales of palm trees from Nahal Hever; e.g. Alzoubi (2012, No. $\left.41^{/ 21}\right)$ : 
whrp $w^{c} l l h w^{\prime} r^{c} n$ wkrmyn wbtyn

and dates (or crops) and harvest and the land parcels and the vineyards and the houses.

Yadin et al. $\left(2002\right.$, No. $\left.1^{121}, 179\right)$ translated it as dates. The term is the equivalent of the Akkadian hurpu (CAD Vol. 6, p. 252) which means 'the early crops'. It

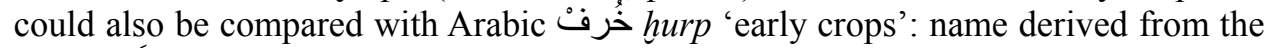
root خَرَفْ harapa meaning 'to cut and gather crops'.

rqq' 'swamp, marsh'

The term has been noted in the Nabataean contracts of sale of palm trees as sing. emph. $r q q$ ' 'the swamp' (Yadin et al. 2002, Nos $2 /^{5,24} ; 3^{15,27}$ ); e.g. Yadin et al. (2002, No. $\left.2^{15}\right)$ :

wlym $>y<n$ ' 'r' $m r$ ['n]' $r b^{\prime} l m l k$ ' $m l k^{5} n b t w d y$ ' [hy]y wšyzb ' $m h$ [wl]šm 'l' $r q q$ ' and to the south: the land of [ou]r lor[d] Rabel the king, king of the Nabataeans - who has brought [li]fe and deliverance to his people; [and to] the north: the swamp.

The term could be compared to Akkadian raqqatu 'swamp, marsh' (CAD Vol. 14, p. 170), and with rqt' in JAr., in Syr. and in Mand. Kaufman (1974, p. 88) stated that the limited distribution of the Akkadian suggests that this term is a loan from Aramaic. The term has been noted in an Aramaic ostracon from Edom dating back to the 4th century B.C., and also in Talmudic literature with a Hebraised from (Yadin et al. 2002, p. 219). We can also compare rqq' tothe Arabic الرَّقَّة al-raqqat which means 'the swamp or the flood plain' (Ibn Manzūur 2003, Vol. 4, p. 216).

\section{Debatable Terms}

In addition to the above-mentioned agricultural terms, there are some doubtful and debatable ones. They necessitate further discussions and demonstrations of their proper reading or translation:

\section{Jd'}

$j d$ ' is the reading suggested by al-Theeb (1998, pp. 87-88, No. 55) for the debatable reading of the inscription CIS 294. Al-Theeb maintains this reading also in his $\mathrm{Na}$ bataean Dictionary. He thinks that jd' is the equivalent of the Arabic الجَدَّاد al-jaddād indicating 'the person who collects the dates of the palm trees', and he considers it a new agricultural profession that was adopted by the Nabataeans after their settlement (al-Theeb 2000, pp. 60-61).

Actually, the CIS authors did not suggest any reading or translation for this term (CIS II 249), while Jaussen and Savignac (1909-1914, No. 95) read the term as $j d w$ and did not suggest any explanation. 
After tracing the inscription in al-Theeb (2000, Plate 3, p. 332), we think that Jaussen and Savignac's reading of the term as $j d w$ is more convenient. $J d w$ seems to be a masculine personal name; it frequently surfaces in Nabataean inscriptions (see Negev 1991, p. 18). In addition, الجدّاد al-jaddād in Arabic could also mean the 'winemaker' (Ibn Manz̄ūr 2003, Vol. 3, p. 112).

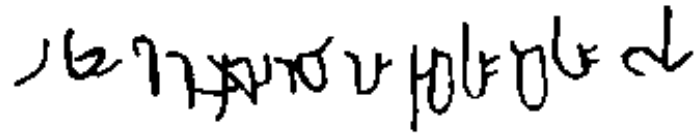

(CIS 294)

\section{prk'}

prk' is the suggested reading of al-Theeb (2000, p. 209) for the last word on the second line of JS 159 from Hegra. He reads the term as prk' and compares it with the Arabic فَرَكَ faraka 'to rub, scrub, chafe', and he states that prk' in Nabataean indicates the harvestman.

Jaussen and Savignac (1909-1914, No. 159) read the term as hprky' and translate it as 'governor, prefect'. After examining the drawing of the text, Jaussen and Savignac's reading seems to be more convenient (see the drawing below); hprk 'governor' is well known in Nabataean as sing. cstr. hprk; sing. emph. hprk'; sing. abs. hprky', hprkyh (Hoftijzer-Jongeling 1995, p. 292).

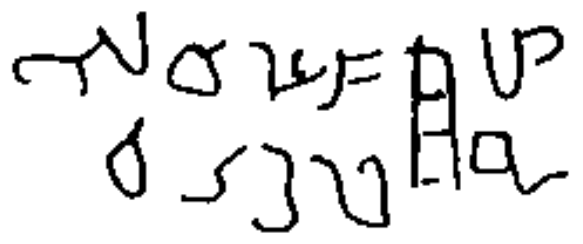

(JS 159)

\section{mdr'/skr'}

The term $m d r$ '/skr' was noted in four Nabataean inscriptions from 'Avdat (ancient Oboda) (see Negev 1961, pp. 127-138; 1963, pp. 113-124). Negev (1961, Nos 7a, $7 \mathrm{~b}, 8 ; 1963$, No. 10) read the term as $s k r$ ' and translated it as 'stop' or 'dam' of a river or rivulet. He also compared it to Assyrian sik(k)uru, and Arabic سكر sekru. This term also appears in the same form in Aramaic and Syriac (Negev 1961, p. 133). Both Levinson (1974, p. 193) and Jobling (1995, p. 57) adopted Negev's reading.

According to Naveh (1967, p. 187), the term could be read as $m d r$ ', $m r d$ ' or $m d d$ ', since the second and the third letters could be either daleth or resh. Naveh recommended to read it as $m d r$ ' and compared it with the Bab. Tal. מדרא 'the water course'. 
On the basis of the image of the inscription (Negev 1961, Plates 30 and 41) and considering that we have to do with vessels destined to contain liquids, we think that Naveh's suggestion is more acceptable.

\section{Conclusion}

Archaeological and epigraphic evidence from the Nabataean Kingdom clearly shows that the Nabataeans were able to use various techniques to collect rain water for agricultural purposes. The existence of a great number of water reserves, dams, water canals and hydraulic system traces, mainly in Petra, Negev and Sinai, indicates that an irrigational system existed, and that the Nabataeans were able to develop agriculture in the arid desert, and use their lands for growing different kinds of agricultural products.

Nabataean inscriptions expose many terms and expressions on the subject of agricultural activities which were known in the Nabataean society. Nabataean agricultural terms display Akkadian, Arabic, Aramaic and Hebrew influences. Most of the terms derive from the Dead Sea Nabataean papyri, the majority of which deal with palm tree land sales.

Names of fruits and crops that the Nabataeans cultivated (e.g. tmr, krmyn, btlt') were noted in different texts, others describe the nature of the land (e.g. ' $r^{c}$ $h r r h)$. Furthermore, some terms shed light on the Nabataean agricultural methods and techniques, such as the irrigation system $\check{s} q y^{\prime}$. Finally, Nabataean inscriptions also contain terms concerning the water harvest system that they used in their agricultural activities, such as $b^{\prime} r w t m y$ ', jb', $m d r$ ' $/ s k r$ '.

\section{Abbreviations}

abs./abst. abstract

Amm. Ammonite

Bab. Tal. Babylonian Talmud

CAD The Assyrian Dictionary of the Oriental Institute of the University of Chicago. Chicago, Ill., Published by the Oriental Institute, 1955

CIS Corpus Inscriptionum Semiticarum. Paris, Académie des Inscriptions et belles lettres, 1907.

cnst./cstr. constructed

emph. emphatic

f. feminine

impf. imperfect

JAr. Jewish Aramaic

KAI Donner, H.-Röllig, W. (1962-1964): Kanaanäische und Aramäische Inschriften. Wiesbaden, Harrassowitz.

m. masculine

Mand. Mandaic

Mo. Moabite 


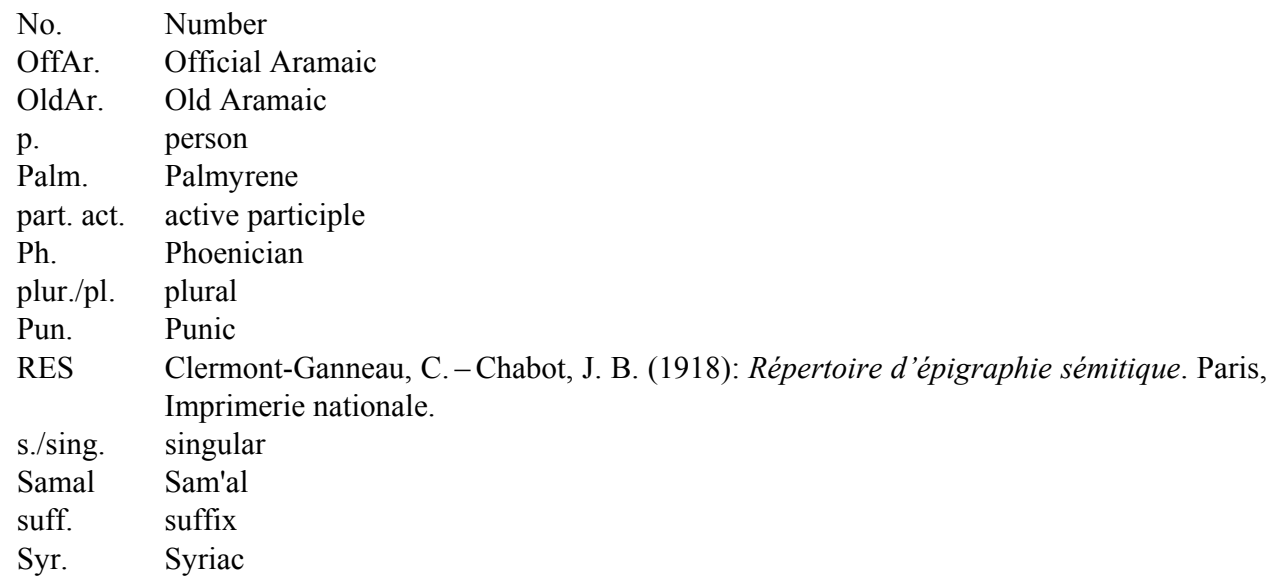

\section{Bibliography}

Alzoubi, M. (2012): Les formule juridiques dans les inscriptions Nabatéennes. Saarbrücken, Presses Académiques Francophones.

Benoit, P. - Milik, J. - de Vaux, R. (1961): Les Grottes de Murabba 'ât. Oxford, Clarendon Press.

Bowersock, G. (1983): Roman Arabia. Harvard, Harvard University Press.

Cantineau, J. (1931-1932): Le Nabatéen, Vol. 2. Paris, Librairie Ernest Leroux.

Cantineau, J. (1936): Tadmorea (1). SYRIA Vol. 17, No. 3, pp. 267-282.

Cotton, H. (1997): Land Tenure in the Documents from the Nabataean Kingdom and the Roman Province of Arabia. Zeitschrift für Papyrologie und Epigraphik No. 119, pp. 255-265.

Cowley, A. (1967): Aramaic Papyri of the Fifth Century B.C. Osnabruck, Otto Zeller.

Delaporte, L. (1912): Epigraphes Araméens. Paris, Diez Merino.

Donner, H. - Röllig, W. (1962-1964): Kanaanäische und Aramäische Inschriften, 3 vols. Wiesbaden, Otto Harrassowitz.

Drive, G. (1957): Aramaic Documents of the Fifth Century B. C. Second Edition. Oxford, Clarendon Press.

Farajat, S. (2008): Petra, the Nabataeans and Nabataean Culture - An Introduction to an Outstanding Site. In: Ohlig, Ch. (ed.): Cura Aquarum in Jordanien. Siegburg, Books on Demad GmbH Nordstedt, Deutschland, pp. 1-12.

Fitzmyer, J. - Harrington, D. (1978): A Manual of Palestinian Aramaic Texts (Second Century B.C.Second Century A.D. Rome, Biblical Institute Press (Biblica et Orientalia 34).

Gelb, I. (1957): Glossary of Old Akkadian. Chicago, University of Chicago Press.

Glueck, N. (1965): Deities and Dolphins: The Story of the Nabataeans. New York, Farrar, Straus and Giroux.

al-Hamoury, Kh. (2002): Mamlakat al-Anbaț. Maan, Bait Alanbaț. (in Arabic)

Healey, J. (1993): The Nabataean Tomb Inscriptions of Mada'in Salih. Oxford, Oxford University Press on behalf of the University of Manchester.

Hoftijzer, J.-Jongeling, K. (1995): Dictionary of the North-West Semitic Inscriptions. LeidenNew York-Cologne, E. J. Brill

Ibn Manẓūr, M. (2003): Lisān al- ${ }^{c}$ Arab. Beirut, Dar Sader.

Jagersma, H. (1981): The Tithes in the Old Testament. Old Testament Studies No. 21, pp. 116-128. 
Jaussen, A. - Savignac, R. (1909-1914): Mission archéologique en Arabie, 2 vols. Paris, La Société des Fouilles Archéologiques.

Jobling, W. (1995): Nabataean-Aramaic: A Provisional Lexicon. Kensington, Md., Dunwoody Press Corp.

Kaufman, S. (1974): The Akkadian Influences on Aramaic. Chicago, Chicago University Press.

Levinson, J. (1974): The Nabatean Aramaic Inscriptions. Ph.D. Dissertation. New York, New York University.

Milik, J. (1968): Parchemin judéo-araméen de Doura-Europos, an 200 ap. J.C. Syria No. 45, pp. $97-$ 104.

Naveh, J. (1967): Some Notes on the Nabatean Inscriptions from ${ }^{\mathrm{c}}$ Avdat. $I E$ No. 17, pp. 486-489.

Naveh, J. (1978): On Stone and Mosaic: The Aramaic and Hebrew Inscriptions from Ancient Synagogues. Jerusalem, Israel Exploration Society.

Naveh, J. (1979): A Nabatean Incantation Text. Israel Exploration Journal No. 29, pp. 111-119.

Negev, A. (1961): Nabatean Inscriptions from 'Avdat (Oboda). Israel Exploration Journal Vol. 11, No. 3, pp. 127-138.

Negev, A. (1963): Nabatean Inscriptions from 'Abdat (Oboda). Israel Exploration Journal Vol. 13, pp. 113-124.

Negev, A. (1986): Nabataean Archeology Today. New York, New York University Press.

Negev, A. (1991): Personal Names in the Nabatean Realm. Jerusalem, Institute of Archaeology, Hebrew University of Jerusalem (Qedem 32).

Segal, J. B. (1983): Aramaic Texts from North Saqqâra, with Some Fragments in Phoenician. London, Egypt Exploration Society.

Siculus, D. - Oldfather, Ch. (1935): Diodorus of Sicily: Library of History. Cambridge, Mass., Harvard University Press.

al-Theeb, S. (1998): Nuqš al-Hajar al-Nabațiyah. Riyadh, King Fahad Library.

al-Theeb, S. (2000): al-Mucjam al-Nabatī. Riyadh, King Fahad Library.

Yadin, Y. (1962): The Scroll of the War of the Sons of Light Against the Sons of Darkness. Oxford, Oxford University Press.

Yadin, Y. (ed.) (2002): The Documents from the Bar Kokhba Period in the Cave of Letters; Hebrew-Aramaic and Nabataean-Aramaic. Jerusalem, Israel Exploration Society.

Yadin, Y.-Greenfield, J. (1989): The Documents from the Bar Kokhba Period in the Cave of the Letters, Aramaic and Nabatean Signatures. Jerusalem, Israel Exploration Society.

Yardeni, A. (2000): Textbook of Aramaic, Hebrew and Nabataean Documentary Texts from the Judaean Desert and Related Material, 2 vols. Jerusalem, Hebrew University Press. 